Intersections

Canadian Journal of Music

Revue canadienne de musique
Intersections CANADAN TOURAL OO UUSIC

\title{
Adrian Thomas. 2005. Polish Music since Szymanowski. Cambridge, UK: Cambridge University Press. 384 pp. ISBN-13: 978-052-105472-0 (paper)
}

\section{Brian Locke}

Volume 28, numéro 2, 2008

URI : https://id.erudit.org/iderudit/029959ar

DOI : https://doi.org/10.7202/029959ar

Aller au sommaire du numéro

\section{Éditeur(s)}

Canadian University Music Society / Société de musique des universités canadiennes

\section{ISSN}

1911-0146 (imprimé)

1918-512X (numérique)

Découvrir la revue

Citer ce compte rendu

Locke, B. (2008). Compte rendu de [Adrian Thomas. 2005. Polish Music since Szymanowski. Cambridge, UK: Cambridge University Press. 384 pp. ISBN-13: 978-052-105472-0 (paper)]. Intersections, 28(2), 109-113.

https://doi.org/10.7202/029959ar

Tous droits réservés (C) Canadian University Music Society / Société de musique des universités canadiennes, 2009
Ce document est protégé par la loi sur le droit d'auteur. L’utilisation des services d'Érudit (y compris la reproduction) est assujettie à sa politique d'utilisation que vous pouvez consulter en ligne.

https://apropos.erudit.org/fr/usagers/politique-dutilisation/ 
Cadrin, Paul. 2004. "Karol Szymanowski and Richard Strauss : Of Diverging Epiphanies ». Revue de musique des universités canadiennes 24, no $2:$ 29-43. Duchesneau, Michel. 1997. L'avant-garde musicale à Paris de 1871 à 1939. Sprimont : Mardaga.

Erhardt, Ludwick. 1974. La musique en Pologne. Paris : Fayard.

Palmer, Christopher. 1987. Szymanowski : Un compositeur à la croisée des chemins, essai traduit de l'anglais par Myriam Tcamitchian-Faure, avec la participation d'Alain Artaud. Arles : Actes Sud.

Samson, Jim. The Music of Szymanowski. London : Kahn and Averill, 1990.

__ [ [2008]. «Szymanowski, Karol». Grove Music Online [en ligne] <http:// www.oxfordmusiconline.com/subscriber/article/grove/music/27328?q=Ka rol+Szymanowski\&search=quick\&pos=1\&_start=1\#firsthit $>$ (consulté le 7 janvier 2009).

Justine Comtois

Adrian Thomas. 2005. Polish Music since Szymanowski. Cambridge, UK: Cambridge University Press. 384 pp. ISBN-13: 978-052-105472-o (paper).

Whether because of language barriers, political divisions throughout history, the lack of readily available materials, or a perceived distance from a "musicological mainstream," the majority of English-speaking music scholars have shied away from studying the artists and repertoires of East Central Europe. In most general histories of modernism, the region is all but ignored in favour of Vienna, Darmstadt, or New York. Richard Taruskin, writing on nationalism and historiography in 1996, famously problematized the "numerus clausus" quota system in the Western canon that draws a sharp line between Janáček and Bartók (among others) and grants a higher status to the latter, on the basis of an imaginary tally of influences on later modernist composers. Indeed, most master narratives of music history disallow close synchronic readings of local musical communities east of the Austro-German lands, such that only a lucky few individuals work their way into the narrative at all-sometimes as lone representatives of an exotic other, and always despite the limitations of their allegedly "peripheral" roots.

Thankfully, finding a substantive account of a musical community from this region has become a less rare event, where the scholarship seeks to gain exposure for the artists and their works, not to judge their apparent worth to subsequent historians, but to document musical events as they occurred. Such a work is Adrian Thomas's Polish Music since Szymanowski, a milestone of scholarship that balances the known and unknown. In this monograph, Thomas presents composers as familiar as Lutosławski and Penderecki alongside Palester, Szabelski, Moszumańska-Nazar, and a host of names barely encountered even in contemporary Poland, all of whom gave lifelong contributions to Polish musical life in the late twentieth century. While international acceptance is certainly acknowledged as laudable, it is not a prerequisite for inclusion 
in Thomas's book, the result being a more thorough account of the community in the period 1937-2000 than any other English-language text.

Thomas begins his narrative with Szymanowski, whom he identifies as the most public representative of Polish music in the early twentieth century, but who was "essentially an outsider" (4). The opening chapter, "Szymanowski and His Legacy," reveals the extent to which this dichotomy of individual versus collective shaped the long-term perception (by Poles and non-Poles) of musicmaking in Poland at this time. Although the interwar generation was especially rich in creativity and cosmopolitan interaction, with many composers such as Tansman and Bacewicz seeking a Parisian education, "these composers, either individually or as a group, have not dispelled the impression that Szymanowski was Polish music in the 1920 and 1930s, an impression which persists by default ... Nevertheless, it is apparent that in the 1930s Szymanowski, notwithstanding his position as a figurehead for the younger generation of composers, became increasingly marginalized" (12-13). For Thomas, this becomes a pivotal point in the narrative of Polish music at mid-century: as we see over the next several chapters, amid radical upheavals in politics and musical practice, artists continually struggled to uphold or overturn the legacy of their lone modernist forebear, more than that of any other famous Polish musician such as Chopin or Moniuszko.

After a brief chapter on musical activities in Poland during the Second World War, the traces of which are mostly no longer extant, Thomas proceeds with his even-handed account of each period of the postwar era, taking care to distinguish generational and political perspectives as each movement gave way to the next. The early to mid-1950s were dominated, as elsewhere in the Communist bloc, by the official doctrine of socialist realism, wherein artists were expected to produce music that was optimistic and collective in its expressive style-and never formalist, which is to say, reminiscent of a bourgeois capitalist mindset, however such a thing may be discovered in the score. The author's touchstone here is the August 1949 conference of the Polish Composers' Union held at Łagów, which witnessed the rise of such doctrinaire ideologues as Zofia Lissa and the precipitous decline of cosmopolitan composers, notably Zbigniew Turski. Thomas presents a fascinating series of speech transcripts from the conference, and the segment that details the rejection of Turski's "Olympic" Symphony (as well as the author's subsequent descriptive analysis of it) can be considered one of the most informative case studies on the topic of socialist realism in print.

Within the decade after Łagów, the most important event to shape Polish music-making was doubtlessly the 1956 "Warsaw Autumn" festival, to which Thomas devotes an entire chapter as well as a full appendix of its programmed repertoire. The music presented here and at subsequent festivals formed the core of the movement known generally as the Polish school of the avant-garde, and Thomas takes pains to reconstruct the musical momentum that developed in the months before and after the first festival. His discussion of the political events and changes in cultural mindset that led up to this watershed moment of openness to the West, however, is brief and represents one of the last glimpses 
of the world beyond the scores of Thomas's composers. While the author does great justice to the music of postwar Polish composers by providing important and highly readable descriptions of their music, with well-chosen examples throughout to illustrate his observations, his historical narrative transfers at this point largely to "the music itself" and becomes a history of musical style and genre. Except for his examination of the subjective viewpoints of the composers-such as those of Bacewicz and Baird, toward artistic expression, contemporary influences from outside Poland, and the inheritance from Szymanowski-Thomas's analytical chapters often imply that such music was created to be autonomous, wholly disconnected from Polish postwar society. One might wonder, while reading his intriguing assessments of lesser-known works such as Baird's opera Jutro (1964-1966) or iconic ones such as Lutosławski's Venetian Games (1961), what the audience's reaction to them was, whether in the form of official criticism or other artists' commentaries.

This is not to say that Thomas relies on a positivist enumeration of musical events without his own interpretation. Indeed, one of the great strengths of his analytical prose is his insertion of qualitative statements that tap into the aesthetic questions raised by a given work, phase of a career, or even artistic generation. For example,

The dreamscapes of Robert Desnos's poem "Les espaces du sommeil" proved irresistible to Lutosławski . . . When composing Les espaces $d u$ sommeil (1975), however, Lutosławski was drawn not only to Desnos's text but also to the structural match with his own creative processes: "its musically tempting imagery, its conveniently pliable structure, and its recurring textural elements" . . . Les espaces also demonstrates Lutosławski's ongoing recourse to the linear deployment of the twelve notes in order to create a constantly shifting harmonic background. This was especially significant where a sense of line was inherent to the concept of a composition ... It was one way to break down any sense of monolithic twelve-note harmony, and he used it with special eloquence in the central slow section formed by the two "Il y a toi" segments which precede the climactic section of Les espaces. (144)

Such a sensitive reading not only draws connections between artistic disciplines but also provids a memorable and vibrant point of entry for the reader into what is for most a challenging repertoire. Thomas thereupon supplies a full-page musical example to illustrate this point, as he does with more than seventy-five other compositions in the book-a priceless resource, considering the inaccessibility of all but a few of the scores.

After the first phase of openness to contemporary European musical developments, Polish composers found the freedom to choose aesthetic paths based on a number of factors, and Thomas elucidates the various tendencies extremely well with his chapter designations in parts 3 ("The Search for Individual Identity") and 4 ("Modernisms and National Iconographies"). Naturally, no one composer fits into a single prescribed category or temporal period, and the author acknowledges this by allowing certain prolific composers (Lutosławski, Penderecki, Górecki, Kilar) a nomadic existence, reappearing in later subsections 
or overlapping in time. To his credit, Thomas never reveals a personal bias within his modernist history, either in implying the need for teleological progress along Western paths of dodecaphonic serialism (or a postmodern rejection of it) or as nostalgia for a pre-modernist past. In fact, his aesthetic discourse continuously takes the side of the individual artist currently under review, most notably Bacewicz and Baird in "The Pull of Tradition" and Penderecki and Schaeffer in "Sonorism and Experimentalism." All sides receive equal treatment, a credit to Thomas's overall synchronic approach.

As the narrative approaches the waning years of communism in the late 1980s, with the rise of new generational perspectives in the era of Solidarność, the musical examples begin to reflect the accelerating changes in Polish society. Perhaps most effectively, Thomas explores the relationship in the 1980s between the resurgence of Polish Catholicism and communist state, one that "was to prove crucial on all fronts" (253). The topic occasions an examination of Penderecki's iconic status in this regard, stemming from the 1966 premiere of his St. Luke Passion; both Catholicism and the subsequent reinvestigation of folk musics (the first since the years of Szymanowski's ballet Harnasie) provide ample ground for the analysis of Górecki's later, "postmodern" works. Thomas further characterizes the "Young Poland" generation that emerges in this era as "increasingly unafraid of becoming involved in the struggle for a new Poland, on both the political and cultural front" (290). Judging from its treatment in the text, it would seem that Thomas regards the momentum of change in these years to have more significance for compositional practice and musical aesthetics than the fall of the Iron Curtain in 1989, which receives little comment: understandably, most of the musical developments he traces traverse both periods, with a similar roster of artists active in the community. Demonstrating perhaps the greatest sensitivity toward culturo-political events is the chapter "Emigré Composers," where the decisions of artists such as Szalonek, Palester, and most importantly Panufnik reveal a constant negotiation of Polish identity amid waves of rejection and acceptance in their homeland.

Adrian Thomas's Polish Music since Szymanowski is a necessary acquisition for musicologists interested in postwar modernism, as it presents a thorough account of compositional activities from a musical centre outside the "mainstream." His attention to the aesthetic subtleties of the compositions throughout his narrative make it remarkably engaging for the reader, who comes away with an intimate understanding of such complex music, and a desire to experience it firsthand.

\section{Bibliography}

Chew, Geoffrey, ed. Socialist Realism and Music. Musicological Colloquium at the Brno International Music Festival, vol. 36 (2001).

Jacobson, Bernard. A Polish Renaissance. London: Phaidon, 1996.

Laks, Szymon. Music of Another World. Evanston: Northwestern University Press, 1989. 
Rae, Charles Bodman. The Music of Lutosławski. 3rd ed. London: Omnibus, 1999.

Robinson, Ray, ed. Studies in Penderecki. Vol. 1. Princeton: Prestige, 1998.

Stucky, Steven. Lutosławski and His Music. Cambridge: Cambridge University Press, 2001.

Szymanowski, Karol. Szymanowski on Music: Selected Writings of Karol Szymanowski. Edited and translated by Alistair Wightman. London: Toccata, 1999.

Taruskin, Richard. "Introduction." Special issue, Repercussions 5, nos. 1-2 (1996): 5-20.

Thomas, Adrian. Bacewicz: Chamber and Orchestral Music. Los Angeles: Polish Music Reference Center, 1985.

. "File 750: Composers, Politics, and the Festival of Polish Music (1951)." Polish Music Journal 5, no. 1 (Summer 2002), http://www.usc.edu/dept/ polish_music/PMJ/issues.html.

_- Górecki. Oxford: Oxford University Press, 1997.

Wightman, Alistair. Karol Szymanowski: His Life and Work. Aldershot: Ashgate, 1999.

BRIAN LOCKE

Tanya Kevorkian. 2007. Baroque Piety: Religion, Society, and Music in Leipzig, 1650-1750. Aldershot: Ashgate. xiii, 251 pp. ISBN 978-0-7546-5490-2 (paper).

This publication paints a tremendously valuable "big picture" of religion, religious culture, and the conflict between Pietists and non-Pietists in Leipzig during the second half of the seventeenth and the first half of the eighteenth century. Judging from the title, music seems to have played a minor role before and during J. S. Bach's tenure as Kantor. Yet Kevorkian opens with a resounding "In August 1730, in a lengthy and impassioned memo to the Leipzig town council, Johann Sebastian Bach complained bitterly about his working conditions," noting that "Bach is better understood ... in the context of the sprawling social, cultural, and political system that was the urban public religious arena of the Baroque era" (1). Moreover, musicology is listed as the second of three disciplinary areas upon which the book builds, the others being the social history of religion and Pietist history (3). This presents the question of how much the following eight chapters will indeed touch on the role of music (and by extension musicians) in the religious life of a major city in central Germany over the course of a century.

Music features prominently in the first main section entitled "Congregant's Everyday Practices," a fascinating topic that is familiar to many of us. ${ }^{1}$ Kevorkian

1 See Kevorkian's groundbreaking article, “The Reception of the Cantata during Church Services in Leipzig, 1700-1750," Early Music 30 (2002): 26-45, reprinted in Bach's Changing World, ed. Carol Baron, 174-189 (Rochester: University of Rochester Press, 2006). 